\title{
Editorial: Essential Biomolecules Caught in the Food Web?
}

\author{
Dörthe C. Müller-Navarra ${ }^{1,2 *}$ and Liliane Ruess ${ }^{3 *}$ \\ ${ }^{1}$ Department of Biology, Universität Hamburg, Hamburg, Germany, ${ }^{2}$ Faculty of Mathematics, Informatics and Natural \\ Sciences, University of Hamburg, Hamburg, Germany, ${ }^{3}$ Institut für Biologie, Humboldt-Universität zu Berlin, Berlin, Germany
}

Keywords: essential biomolecules, fatty acids (FA), amino acid (AA), sterol, vitamins, trophic interaction, trophic markers, food web

\section{Editorial on the Research Topic}

\section{Essential Biomolecules Caught in the Food Web?}

The recognition of food chains and food webs was central to ecological concept-building. In his inspiring paper, Pomeroy (2001) highlighted some characteristics of the food web, e.g., energy flow, assimilation efficiency, food chain length, and stability, but still left many food web paradigms unresolved. A major challenge is the complex redundancy of natural food webs, which has so far hindered the application of many models to the real world. Essential biomolecules, in their function as nutritional food components (Müller-Navarra, 2008) or as trophic markers (Ruess and Chamberlain, 2010), are a means for structuring food web complexity.

Due to their potential limiting capacity, essential biomolecules are a determinant of food quality, which affects trophic connectivity and transfer efficiency. This applies especially to the link between

\section{OPEN ACCESS}

\author{
Approved by: \\ Dennis Murray \\ Trent University, Canada \\ *Correspondence: \\ Dörthe C. Müller-Navarra \\ doerthe.mueller-navarra@ \\ uni-hamburg.de \\ Liliane Ruess \\ liliane.ruess@hu-berlin.de
}

Specialty section:

This article was submitted to

Population and Evolutionary

Dynamics,

a section of the journal

Frontiers in Ecology and Evolution

Received: 13 September 2019 Accepted: 21 November 2019 Published: 10 December 2019

Citation:

Müller-Navarra DC and Ruess L (2019) Editorial: Essential Biomolecules Caught in the Food Web? Front. Ecol. Evol. 7:471. doi: 10.3389/fevo.2019.00471 primary producers and their consumers, i.e., the plant-animal interface, at which differences in biochemical make-up and biomass transfer are greatest among food webs. For example, trophic transfer efficiency is attributed to the production of long-chain polyunsaturated fatty acids (LC$\omega 3$ PUFA) at the primary producer level, influencing the shape of the Eltonian biomass pyramid of the ecosystem (Brett and Müller-Navarra, 1997). In addition, trophic upgrading by heterotrophic flagellates and protozoans [i.e., the conversion to LC-w3PUFA from their biochemical precursors; (Klein-Breteler et al., 1999)] can be critical for trophic transfer when primary production is by autotrophic picoplankton. However, not only heterotrophs, such as animals, but also auxotrophs, such as many algae, rely on the external provision of essential biomolecules (Croft et al., 2006; Tang et al., 2010), e.g., vitamin $B_{12}$ provided by certain Archaea (Doxey et al., 2015).

Although essential biomolecule dynamics are of general ecological importance, the most comprehensive knowledge exists for lipids, with a strong bias toward aquatic systems (Arts et al., 2009). Consumer synthesis capacities seem to determine the length of food chains, especially when depending on low food-quality resources. In detrital systems, mainly based on recalcitrant organic carbon, the presence of $\omega 3$ PUFA is important for decomposition processes (Vonk et al., 2016). Due to the synthesis of LC-w3PUFA in adapted consumers (Menzel et al.), detrital food chains can be long, dissipating the energy from the low-quality organic matter step-by-step. Terrestrial herbivores such as ruminants use gut endosymbionts that not only make cellulose carbon available to the host but also play a vital role in vitamin synthesis (Magnúsdóttir et al., 2015) and amino acid provision (Larsen et al., 2016).

From an evolutionary standpoint, however, food web interactions are the means by which heterotrophic organisms acquire and compete for essential biomolecules. Generally, essential biomolecules are those for which syntheses are elaborative, requiring several steps in the synthesis chain. Being under evolutionary constraint, there are circumstances under which the loss of synthesis becomes a selective advantage (Ellers et al., 2012), e.g., when those 
biomolecules are provided as common goods by other members of the consortium (Black Queen Hypothesis) or are ample in food ("relaxed selection") or otherwise functionally compensated for (“environmental compensation").

With sufficient understanding of the biochemical and biomolecular traits of both diet and consumer organisms (Karasov and Martínez del Rio, 2007; Steinberg, 2018), essential biomolecules can be used as trophic markers to assign and quantify trophic interactions. Primarily fatty acids (Budge et al., 2008; Ruess and Chamberlain, 2010) and stable isotope signals of amino acids (Steffan et al., 2013; Takizawa et al., 2017) can be used to unravel feeding histories in natural food webs.

Together, the contributions to this Research Topic in Frontiers in Ecology and Evolution mirror the diverse roles of nutritionally important essential biomolecules in food web ecology and evolution.

Focusing on the laboratory model organism and planktonic keystone genus Daphnia, Martin-Creuzburg et al. studied sterol and eicosapentaenoic acid (EPA, a LC-w3PUFA)limitation in Daphnia magna males and females. They conclude that, while sterol requirements differed between males and females, their thresholds for EPA-limited juvenile growth were comparable. In contrast, females preferentially benefitted from EPA supplementation because of high demands in reproduction, i.e., egg production. In light of global warming, von Elert and Fink show in a laboratory study of D. magna and the green alga Chlamydomonas klinobasis that not only the temperature per se but also temperature-mediated differences in PUFA availability affected the growth rates of these zooplankters. In a three-level food chain model, Chi et al. demonstrate that vitamin $B_{1}$ affected the relative LC- $\omega 3$ PUFA pattern in the flagellate Rhodomonas baltica, being transferred to the next trophic level, the copepod Acartia tonsa. However, when feeding these to Aurelia aurita, the polyps contained few LC- $\omega 3$ PUFA. To determine the importance of biomolecule availability for secondary production, Peltomaa et al. analyzed several phytoplankton monocultures for a diverse set of essential biomolecules, including essential amino and fatty acids as well as sterols. Experiments with D. magna revealed that food from different algal classes resulted in different growth responses. Based on projection onto phytoplankton compositions from the field, they concluded that zooplankton are likely to be sterol-limited in lakes dominated by cyanobacteria. Schram et al. used fatty acids as markers for trophic interactions

\section{REFERENCES}

Arts, M. T., Brett, M. T., and Kainz, M. (2009). Lipids in Aquatic Ecosystems. New York, NY: Springer.

Brett, M. T., and Müller-Navarra, D. C. (1997). The role of highly unsaturated fatty acids in aquatic food web processes. Freshw. Biol. 38, 483-499. doi: 10.1046/j.1365-2427.1997.00220.x

Budge, S. M., Wooller, N. J., Springer, A. M., Iversen, S. J., and Divoky, G. J. (2008). Tracing carbon flow from the bottom to the top in an Arctic marine food web using fatty acid-stable isotope analysis. Oecologia 157, 117-129. doi: $10.1007 /$ s00442-008-1053-7 between macro-algae of three different classes (Nereocystis luetkeana, Ulva sp., Pyropia sp.) and two species of sea urchins (Strongylocentrotus droebachiensis, S. purpuratus). The sea urchins had elevated LC-PUFA levels, greater than those in their food, yet the fatty acid pattern in the sea urchin tissue was still related to the algae phyla. The work of Menzel et al. extends the perspective to terrestrial food webs, here looking at soil decomposers. They highlight nematodes as an important source for LC- $\omega 3$ PUFA, which, in contrast to in aquatic systems, are not widely available in terrestrial habitats. Using PUFA-deficient strains of Caenorhabditis elegans, they show that the fitness of Collembola, small soil arthropods, benefits from PUFA supplementation in the diet. Despite this, Collembola possess the metabolic capability for de novo synthesis of these nutritionally valuable biomolecules. Finally, Ruess and Müller-Navarra review nutritionally important biomolecules and their physiological functions, input, and dynamics in food webs. They show that these dynamics are very characteristic of ecosystems and the links across ecosystems. In addition, the stable isotope dynamics of essential biomolecules are especially valuable trophic tracers to characterize food web structure and function. Moreover, specific environmental conditions can favor the evolution of consumers' external reliance on nutritionally valuable biomolecules, and the many types of trophic interactions can be viewed as adaptations for their acquisition, in order to maximize the consumer's fitness.

Taken together, the articles in this special issue highlight the central role of essential biomolecules for heterotrophic consumers as potential limiting resources and their physiological traits, as well as their indispensability as trophic tracers in natural food webs.

\section{AUTHOR CONTRIBUTIONS}

DM-N and LR came up with the topic idea, contributed to its description and the overall organization of the special topic, and wrote the cover editorial. All editors contributed to the overseeing of reviews for this special issue.

\section{ACKNOWLEDGMENTS}

We wish to thank all the contributing authors, reviewers and editors for their efforts and suggestions which were much appreciated. Eukaryot. Cell 5, 1175-1183. doi: 10.1128/EC.00097-06

Doxey, A. C., Kurtz, D. A., Lynch, M. D. J., Sauder, L. A., and Neufeld, J. D. (2015). Aquatic metagenomes implicate Thaumarchaeota in global cobalamin production. ISME J. 9, 461-471. doi: 10.1038/ismej.2014.142

Ellers, J., Kiers, E. T., Currie, C. R., McDonald, B. R., and Visser, B. (2012). Ecological implications drive evolutionary loss of traits. Ecol. Lett. 15, 1017-1082. doi: 10.1111/j.1461-0248.2012.01830.x

Karasov, W. H., and Martínez del Rio, C. (2007). Physiological Ecology: How Animals Process Energy, Nutrients and Toxins. Princeton, NJ; Oxford: Princeton University Press. 
Klein-Breteler, W. C. M., Schogt, N., Baas, M., Schouten, S., and Kraay, G.W. (1999). Trophic upgrading of food quality by protozoans enhancing copepod growth: role of essential lipids. Mar. Biol. 135, 191-198. doi: $10.1007 / \mathrm{s} 002270050616$

Larsen, T., Pollierer, M. M., Holmstrup, M., D’Annibale, A., Maraldo, K., Andersen, N., et al. (2016). Substantial nutritional contribution of bacterial amino acids to earthworms and enchytraeids: a case study from organic grassland. Soil Biol. Biochem. 99, 21-27. doi: 10.1016/j.soilbio.2016.03.018

Magnúsdóttir, S., Ravcheev, D., de Crécy-Lagard, V., and Thiele, I. (2015). Systematic genome assessment of B-vitamin biosynthesis suggests cooperation among gut microbes. Front. Microbiol. 6:148. doi: 10.3389/fgene.2015.00148

Müller-Navarra, D. C. (2008). Food web paradigms: the biochemical view on trophic interactions. Internat. Rev. Hydrobiol. 93, 489-505. doi: 10.1002/iroh.200711046

Pomeroy, L. R. (2001). Caught in the food web: complexity made simple? Sci. Mar. 65, 31-40. doi: 10.3989/scimar.2001.65s231

Ruess, L., and Chamberlain, P. M. (2010). The fat that matters: soil food web analysis using fatty acids and their carbon stable isotope signature. Soil Biol. Biochem. 42, 1898-1910. doi: 10.1016/j.soilbio.2010.07.020

Steffan, S. A., Chikaraishi, Y., Horton, D., Ohkouchi, N., Singleton, M. E., Miliczky, E., et al. (2013). Trophic hierarches illuminated via amino acids isotopic analysis. PLoS ONE 8:e76152. doi: 10.1371/journal.pone.0076152

Steinberg, C. E. W. (2018). "Introduction - 'You are what you eat"' in Aquatic Animal Nutrition - A Mechanistic Perspective Form Individuals to Generations, ed. C. E. W. Steinberg (Basel: Springer), 1-7. doi: 10.1007/978-3-31991767-2_1

Takizawa, Y., Dharampal, P. S., Steffan, S. A., Takano, Y., Ohkouchi, N., and Chikarashi, Y. (2017). Inter-trophic isotopic discrimination of $15 \mathrm{~N} / 14 \mathrm{~N}$ for amino acids in autotrophs: implications for nitrogen dynamics in ecological studies. Ecol. Evol. 7, 2916-2924. doi: 10.1002/ece3.2866

Tang, Y. Z., Koch, F., and Gobler, C. J. (2010). Most harmful algal bloom species are vitamin B1 and B12 auxotrophs. Proc. Natl. Acad. Sci. U.S.A. 107, 20756-20761. doi: 10.1073/pnas.1009566107

Vonk, J. A., van Kuijk, B. F., van Beusekom, M., Hunting, E. R., and Kraak, M. H. S. (2016). The significance of linoleic acid in food sources for detritivorous benthic invertebrates. Sci. Rep. 6:35785. doi: 10.1038/srep35785

Conflict of Interest: The authors declare that the research was conducted in the absence of any commercial or financial relationships that could be construed as a potential conflict of interest.

Copyright (C) 2019 Müller-Navarra and Ruess. This is an open-access article distributed under the terms of the Creative Commons Attribution License (CC BY). The use, distribution or reproduction in other forums is permitted, provided the original author(s) and the copyright owner(s) are credited and that the origina publication in this journal is cited, in accordance with accepted academic practice. No use, distribution or reproduction is permitted which does not comply with these terms. 